diastolic pressure gradient the Austin Flint murmur could well be due to forward flow of blood through a functionally narrowed mitral valve, as originally suggested. In more severe cases, however, with a reversed pressure gradient, diastolic mitral incompetence seems to be a likely explanation of the pathogenesis of the murmur.

\section{Coal Mining, Pneumoconiosis, and Lung Cancer}

In 1936 N. M. Kennaway and E. L. Kennaway ${ }^{1}$ drew attention to the low mortality from lung cancer among coal miners as compared with the general male population. Further studies by the Kennaways ${ }^{23}$ and by other workers ${ }^{4-6}$ led to the same conclusion; and according to the Decennial Supplement of the Registrar General published in $1938^{\prime}$ the standardized mortality ratio (S.M.R.) for lung cancer in men working on the coal face for the three years, 1930-2 was 67 (compared with 100 for all males). The S.M.R. for lung cancer in underground workers in coal mines other than coalface workers was lower still-namely, 36 . In a more critical study conducted in South Wales W. R. L. James ${ }^{8}$ found lung cancer at necropsy in $5.4 \%$ of 1,531 non-miners but in only $3.3 \%$ of 1,827 coal miners. When he subdivided the miners into those with simple pneumoconiosis and those with progressive massive fibrosis (P.M.F.) the rates were $5.1 \%$ and $1.4 \%$, respectively. More recently K. P. Goldman ${ }^{9}$ has analysed unpublished data collected by the Medical Research Council's Epidemiology Unit in South Wales. These data consisted of records of radiological examinations for pneumoconiosis and information on causes of death as written on death certificates for a community of 5,096 miners and ex-miners in the Rhondda Fach Valley in Glamorganshire. The results of Goldman's analysis were somewhat in conflict with the findings of $\mathrm{James}^{8}$ : the mortality from lung cancer was highest, and equal to the national average, among miners with P.M.F., lowest in those with simple pneumoconiosis, and intermediate in those free of radiological evidence of dust disease.

Both James ${ }^{8}$ and R. A. Smith ${ }^{10}$ reported that survival rates are better than average in miners after surgical resection of lung cancer. Goldman ${ }^{11}$ investigated this phenomenon in a careful retrospective survey of cases of primary lung cancer who attended the regional thoracic centre for South Wales between 1954 and 1960. The case material included 172 miners and 518 non-miners, and was analysed according to age, sex, smoking habits, length of time symptoms were present, respiratory function, tumour histology, method of treatment, and survival. In addition, the 172 miners were classified according to degree of pneumoconiosis as assessed radiologically. The miners as a group had a slightly reduced forced expiratory volume (F.E.V.), but differences between miners and non-miners in smoking habits, length of symptoms, average age at onset of symptoms, and spectrum of tumour types were small. Similar proportions of miners and nonminers were deemed operable, but, as noted by T. F. Nealon, ${ }^{12}$ the immediate operative mortality was higher in the former. Survival during the five years after operation or diagnosis was similar in miners and non-miners, both for the inoperable cases and for the surgically treated cases who survived the first 28 days after operation. However, among miners, whether treated by surgery or not, survival time during the two years after diagnosis increased with the severity of simple pneumoconiosis as determined radiologically.

It has been suggested ${ }^{1011}$ that this better survival from lung cancer in the presence of pneumoconiosis may be due to the blockage of lymphatics by fibrosis and particle-laden macrophages, ${ }^{13}$ which serves to prevent the dissemination of cancer cells. It would be tempting to argue that the same factor could be responsible for the reduced incidence of clinically recognized lung cancers in miners, but this is unlikely in so far as Goldman found evidence of better survival from the disease only in the minority of miners with the more severe grades of simple pneumoconiosis. A mere excess of coal dust in the lungs in the absence of radiological evidence of pneumoconiosis did not affect survival time.

The difficulties of studies of this kind can scarcely be exaggerated. For instance, the diagnosis of lung cancer is rendered difficult by the presonce of pneumoconiosis. ${ }^{12} 14$ is A miner, particularly a pneumoconiotic, is more likely than a non-miner to be under radiological surveillance, with the result that lung cancer may be diagnosed earlier. Also one must question whether sufficient account has been taken of exposure to tobacco smoke. It is true that many workers ${ }^{16-21}$ have either failed to find much difference between miners and non-miners in relation to their smoking habits or have observed that the smoking habit is more prevalent among miners than in the general population. However, the results of three surveys ${ }^{17-19}$ indicated that the proportion of miners who are heavy smokers is lower than for the general population. Furthermore, according to G. F. Todd, ${ }^{22}$ though miners were smoking more than the average for all social classes in 1958, the position was reversed by 1961 . An underground worker is precluded from smoking during most of his working day. The accumulated effect of these differences might be important in relation to the lowered incidence of, and better survival from, lung cancer in miners.

D. J. B. Ashley ${ }^{23}$ has recently drawn attention to an excessive mortality from bronchitis and a reduced mortality from lung cancer in areas of England and Wales where coal mining and textile industries are prominent. He excludes the possibility that differences in exposure to general air pollutants may be responsible, but does not consider the

Kennaway, N. M., and Kennaway, E. L., F. Hyg. (Lond.), 1936, 36, 236.

2 Kennaway, E. L., and Kennaway, N. M., Brit. F. Cancer, 1947, 1, 260.

ibid., 1953, 7, 10.

Gooding, C. G., Lancet, 1946, 2, 891.

McVittie, J. C., Postgrad. med. F., 1949, 25, 618

- Chatgidakis, C.’ B., Brit. F. industr. Med., 1963, 20, 236

Registrar General, Decennial Supplement, England and Wales 1931, Part II a, Occupational Mortality, 1938. H.M.S.O., London.

- James, W. R. L., Brit. ₹. industr. Med., 1955, 12, 87.

- Goldman, K. P.; ibid., 1965, 22, 72.

10 Smith, R. A., ibid., 1959, 16, 318.

11 Goldman, K. P., Thorax, 1965, 20, 170.

12 Nealon, T. F., Arch. environ. Hlth, 1964, 8, 882.

18 Heppleston, A. G., F. Path. Bact., 1947, 59, 453.

14 Goldman, K. P., Brit. Ұ. Dis. Chest, 1965, 59, 141.

is Gernez-Rieux, "C., Voisin, C., Balgairies, E., Delepoulle, E., and Lenoir, L., Lille méd., 1961, 6, 551.

16 Higgins, I. T. T., Oldham, P. D., Cochrane, A. L., and Gilson, J. C., Brit. med. F., 1956, 2, 904.

is Ashford, J. R., Brown, S., Duffieid, D. P., Smith, C. S., and Fay, J. W. J., Brit. Ұ. prev. soc. Med., 1961, 15, 106.

19 Todd, G. F., Statistics and Smoking, Research Papers No. 1, 2nd edition, Tobacco Manufacturers Standing Committee, 1959.

20 Cross, K. W., McDowell, L. A., and Posner, E., Brit. med. 7., 1958,

21 Brown, S., Report No. Sc 849/MR/41, National Coal Board Scientific Department, 1962 . London.

22 Todd, G. F, Statistics of Smoking, Research Papers, No. 1, 3rd edition, Tobacco Research Council, 1962. London.

23 Ashley, D. J. B., Brit. Y. Cancer, 1967, 21, 243.

24 Old, L. L., Benacerraf, B., Clarke, D. A., Carswell, E. A., and Stockert, E., Cancer Res., 1961, 21, 1281. 
possible influence of differences in smoking habits. His suggestion that "the dusty lung is in a state of enhanced immunological competence and is better able to destroy the first few cells which have undergone malignant transformation than is the normal lung," though interesting, must be regarded as highly speculative. L. L. Old and his colleagues ${ }^{24}$ reported that in mice B.C.G. infection non-specifically increases resistance both to isologous tumour grafts and to the induction of cancer by 3-methylcholanthrene. However, in general, the function and importance of immune mechanisms in relation to carcinogenesis are far from clear, and certainly in the present instance it would be wise to defer detailed consideration of possible mechanisms until the facts are more certain.

\section{Foot-and-mouth Disease in Man}

True foot-and-mouth disease in man is a very rare infection. During outbreaks of the disease in cattle vesicular eruptions in patients who have come into contact with infected animals naturally incur suspicion, but a diagnosis of foot-and-mouth disease confirmed by laboratory investigation is hardly ever made. Cases described have been mainly from Germany and Scandinavia, where large epizootics have been more frequent than in Britain. In 1939 A. Flaum ${ }^{1}$ described four cases occurring during an epizootic which affected 4,300 herds of cattle in southern Sweden-a worse outbreak than that now in England, grievous though this one is. More recently W. Pilz and H. G. Garbe ${ }^{2}$ have published excellent colour photographs of the hand lesions in two patients infected in the laboratory. These and nearly all previously reported cases have been due to type $O$ virus, though one case due to type $\mathrm{C}$ virus has been recorded. ${ }^{3}$ Incubation periods have, been from three to five days.

On page 529 in the B.M.F. this week a case due to type $O$ virus in a Northumberland man is described. The signs and symptoms were similar to those in the European casesmoderate fever (up to $39.5^{\circ} \mathrm{C}$. is common) preceding the eruption, inflamed throat, painful lesions on the tongue, and blisters on the hands and feet. An unusual feature, not previously described, was the recurrent crops of blisters from which no virus could be isolated. It may be that in this patient a pre-existing skin disorder may have reduced the normally very high human resistance to infection by foot-andmouth disease virus. One of Pilz and Garbe's ${ }^{2}$ patients had been subject to neurodermatitis of long standing. As in other cases, the blisters in the Northumberland man healed in a week. Also characteristically, virus in high titre was recovered from blisters, and the titres of both complement-fixing and neutralizing antibodies diminished rapidly after convalescence.

1 Flaum, A., Acta path microbiol. scand., 1939, 16, 196.

2 Pilz, W., and Garbe, H. G., Zbl. Bakt I., Abt. Orig., 1965, 198, 154. s Eissner, G., Böhm, H. O., and Jülich, E., Dtsch. med. W schr., 1967, 92, 830 .

- Vetterlein, W., Zbl. Bakt. I., Abt. Orig., 1955, 162, 4.

- Alsop, J., Flewett, T. H., and Foster, J. R., Brit. med. F., 1960, 2, 1708 .

- Flewett, T. H., Warin, R. P., and Clarke, S. K. R., 7. clin. Path., $1963,16,53$.

Clarke, S. K. R., Morley, T., and Warin, R. P., Brit. med. F., 1964, 1, 58.

- Anyon, C. P., Duff, S. M. F., and Hamilton, W., N.Z. med. 3., 1967,

- Higgins, P. G., Ellis, E. M., Boston, D. G., and Calnan, W. L., Mith. Bull. Minist. Hlth Lab. Sero., 1965, 24, 38.

10 Froeschle, J. E., Nahmias, A. J., Feorino, P. M., McCord, G., and Naib, Z., Amer. J. Dis. Child w 1967, 114, 278.

11 Born, W., Dtsch. Arrtebl.-Ärztl. Mitt., 1967, 64, 1703.
Human resistance is normally so high that several attempts to infect humans artificially by injecting blister fluid from animals have failed; no lesions were produced and virus could not be recovered from the volunteers' blood at any time after the injection. Subclinical infection is exceedingly rare. Antibodies have been reported in a few laboratory workers exposed over long periods to a high level of infection; in one series five workers were found to have acquired neutralizing antibodies. ${ }^{4}$ Only one such case is known in Britain.

Early failures to infect experimental animals from supposed cases of human foot-and-mouth disease are much more easily explained. The cases may really have been hand-foot-andmouth disease, a not uncommon human infection first described in Britain at a time when there were numerous outbreaks of foot-and-mouth disease in cattle. ${ }^{5}$ This syndrome is not due to foot-and-mouth virus but is caused by a Coxsackie virus, usually type $\mathrm{A} 16$, occasionally $\mathrm{A} 5^{6}$ or $A 10 .^{78}$ The lesions differ from those of foot-and-mouth in rarely reaching $5 \mathrm{~mm}$. diameter, and they never reach the size (1-2 cm. diameter) seen on hands infected with footand-mouth virus. In children especially, maculopapular lesions are often present on the buttocks-whence it has been suggested that a better name might be "hands, mouth, and bumps-a-daisy disease." Fever is rare ; the lesions usually clear up in a week. Excellent black-and-white ${ }^{910}$ and colour $^{11}$ photographs have been published.

Differentiation between the two diseases is not likely to be difficult except in the early stages of the eruption. But if there is the slightest question of a human vesicular eruption infection being foot-and-mouth disease the medical officer of health should be informed and the patient should be isolated in hospital for eight days. Specimens from possible cases of human infection should not be sent to any laboratory other than the Animal Virus Research Institute at Pirbright. Both Coxsackie and foot-and-mouth viruses are easily isolated in suckling mice; and it might be all too easy for a virus as infectious to animals as foot-and-mouth to escape from a laboratory less well designed to contain it than that at Pirbright. The Pirbright laboratory staff must be working overtime at present; nevertheless, a fresh case of human infection, should one occur, might well repay investigation. None of the published descriptions mention, for example, whether virus is excreted in the urine or faeces and if so for how long. It might be important to know this.

\section{Intestinal Absorption}

The intestine has been turned inside out and back to front in order to understand the physiology of intestinal function. More recently a series of new techniques-electron microscopy, histochemistry, autoradiography, radioisotopes, chromatography-have been adapted to the investigation of the structure and function of the intestinal epithelial cell. D. H. Smyth ${ }^{1}$ has aptly described the life of this remarkable cell as a short and merry one, if merriment is the equivalent, in cellular terms, of a range of activities possessed by few other cells in the body. Its life is brief, for the epithelial lining of the intestine is renewed every few days.

This and related topics of intestinal absorption are well reviewed in a recent British Medical Bulletin. Histochemical techniques have proved helpful in interpreting the absorptive

\footnotetext{
1 Smyth, D. H., Brit. med. Bull., 1967, 23, 205.
} 